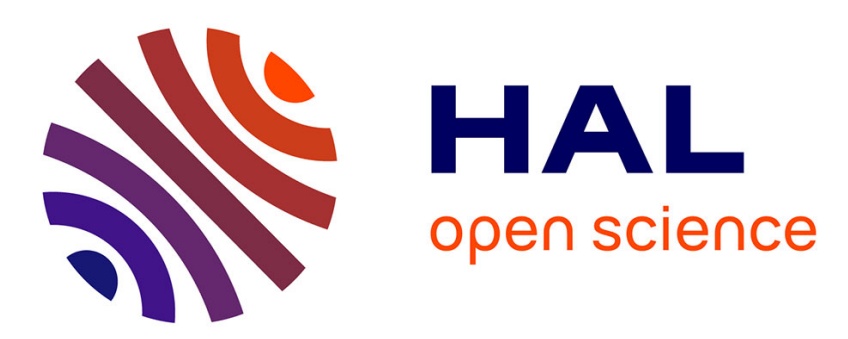

\title{
The World Federation of Neurology and the challenges in Environment Neurology
}

J. Reis, W. Grisold, Ş. Öztürk, M. Wasay, G.C. Román, W.M. Carroll

\section{To cite this version:}

J. Reis, W. Grisold, Ş. Öztürk, M. Wasay, G.C. Román, et al.. The World Federation of Neurology and the challenges in Environment Neurology. Revue Neurologique, 2019, 175, pp.742 - 744. 10.1016/j.neurol.2019.08.006 . hal-03488520

\section{HAL Id: hal-03488520 \\ https://hal.science/hal-03488520}

Submitted on 21 Dec 2021

HAL is a multi-disciplinary open access archive for the deposit and dissemination of scientific research documents, whether they are published or not. The documents may come from teaching and research institutions in France or abroad, or from public or private research centers.
L'archive ouverte pluridisciplinaire HAL, est destinée au dépôt et à la diffusion de documents scientifiques de niveau recherche, publiés ou non, émanant des établissements d'enseignement et de recherche français ou étrangers, des laboratoires publics ou privés.

\section{(ㄷ)(1) $\$$}

Distributed under a Creative Commons Attribution - NonCommerciall 4.0 International 


\section{The World Federation of Neurology and the challenges in Environment Neurology}

Jacques Reis ${ }^{1,2 *}$, Wolfgang Grisold ${ }^{1,3}$ Şerefnur Öztürk ${ }^{1,4}$, Mohammad Wasay ${ }^{1,5}$, Gustavo C. Román 1,6, William M. Carroll ${ }^{1,7}$.

1 World Federation of Neurology, Chester House Fulham Green 81-83 Fulham High Street London SW6 3JA United Kingdom

2 University of Strasbourg, Faculty of Medicine, Department of Neurology (Prof Tranchant) CHRU Strasbourg, France,

3 Ludwig Boltzmann Institute for Experimental und Clinical Traumatology, Donaueschingenstraße 13 A-1200 Wien

4 Selçuk University Faculty of Medicine, Department of Neurology, Konya, Turkey, President of the Turkish Neurological Society

5 Aga Khan University, Karachi, Pakistan, World Brain Day Committee, WFN, Pakistan

6 The Jack S. Blanton Distinguished Endowed Chair and professor of neurology, Methodist

Hospital, Houston, Texas, and Weill Cornell Medical College, New York,

7 Department of Neurology, Sir Charles Gairdner Hospital, Nedlands, WA 6009, Australia

*Corresponding author: Prof. Conv. J. Reis 3, rue du loir 67205 Oberhausbergen, France. jacques.reis@wanadoo.fr 


\begin{abstract}
Since its establishment the World Federation of Neurology (WFN) has manifested a keen interest in the environment and its relation to neurological disease. Thus, in 2007 the WFN renamed the "Neurotoxicological Research Group" to "Environmental Neurology Research Group”. In this short article, we review some recent events which illustrate the WFN involvement in Environmental Neurology as well its concerns about global health matters involving environmental issues.
\end{abstract}

Kewords : World Federation of Neurology, World Brain Day, Environmental Neurology Specialty Group, Turkish Neurological Society, Rencontres Internationales Santé Environnement 
The World Federation of Neurology (WFN), shortly after its establishment in 1957, manifested a keen interest in the environment and its relation to neurological disease. Its first President, Ludo Van Bogaert, was convinced that Tropical Neurology (a climate and geographical environment type) was so important that it warranted the full support of the WFN which led to three centers of the Commission on Tropical Neurology to be established; one of each in Asia, South America and Africa. In 2007, the WFN renamed the "Neurotoxicological Research Group" to "Environmental Neurology Research Group", following a proposal of late Prof Leon Prockop (Tampa) and who was the first chair (1). Without that vision, the topic of environment may never have attained its appropriate position within neurology.

Environmental Neurology promotes a translational approach of neurological diseases which is enriched by multiple disciplines, even outside the medical area (Figure1). The WFN continues its support for the environment and tropical neurology through its Tropical and Geographic Neurology, its Migrant Neurology and its Environmental Neurology Specialty Groups. Since its inception, the WFN has spontaneously adopted a large definition of "the Environment" considering first the global issues (climatic and geographical factors) and then more recently, the psychosocial and societal challenges (migrations) and the environmental part in neurological diseases. This is line with Albert Einstein's statement "The environment is everything that isn't me." Even so, the environmental risks factors for diseases per se have until recently not be sufficiently considered.

The increased awareness of the environmental challenges led to an important innovation. In 2017 in Kyoto, the WFN chose to address air quality in its annual World Brain Day (WBD) (2). The World Brain Day in 2018 was dedicated to "Clean Air for Brain Health" which was promoted by the Environmental Neurology Specialty Group $(3,4)$. It had a large impact in the media worldwide and the WFN was able to raise the awareness of neurologists globally for this important topic (5). 
The global and diffuse chemical contamination impacts the nervous system beyond our common knowledge of "Neurotoxicology". On a large scale this has been demonstrated in the most common neurological disorder stroke, in 2018 when the Global Burden of Disease reported a study showing clearly the impact of air pollution both of the outdoor-ambient and indoor-household air (6). The WFN considers that environmental pollution is a major threat and calls for global action by the WHO, its member States and non-State actors. In addition, the WFN was able to point to emergent and often ignored threats, as the contamination of water resources, not only by industrial pollution, but also by several drugs as used in oncology, neurology and psychiatry (7).

Another WFN research group`s initiative was successful in 2018. The WFN has supported the Intropicon (International Tropical and Geographic Neurology Conference) meeting held in conjunction with the Brazilian Society of Neurology and the Pan American Congress of Neurology in Sao Paulo, Brazil which was held in October 2018 (8). Infectious diseases and specific risks (snakebites) in the tropical zone, were the main topics, underlining the tremendous place of communicable diseases in Neurology. The WFN has been active in other global health matters involving environmental issues most notably WHO conferences such as the Regional WHO meeting in September 2017 (Budapest) and September 2018 (Rome), the Montevideo WHO Global conference on NDCs in October 2017, the WHO general assembly in New York (2018) and the Global Burden of Neurological Disorders World Summit in Auckland New Zealand in November 2018. All were attended by senior WFN executives who made contributions (9-11).

The WFN brings also its support to national neurological societies' initiatives. A good example is provided by the Turkish Neurological Society (TNS). The engagement in environmental concerns led the TNS to participate with 18 other Civil Society Organizations that focus on health and nature conservation in Turkey, to the creation of an international platform dedicated to the "Right to Clean Air Platform" in 2015 (12). Obviously the TNS was in a leading position for the 22 July 2018 World 
Brain Day's events (13). The President of the TNS (Prof. Şerefnur Öztürk) and many members of the society contributed with numerous interviews on the social media and conventional media ( $\mathrm{TV}$, radio and news weeks) to initiate an action to reduce air pollution and harmful effects of environment. Prof. Öztürk highlighted the importance of increasing neurological diseases burden in the world and in particularly in Turkey. She pointed to the responsibility of the societies and the governmental bodies to prevent risk factors including air pollution at the meeting for "Clean Air for Brain Health in Istanbul". (14). In addition, during its Annual Neurology Congress, the TNS has introduced a dedicated session on Environmental Neurology.

The International Meeting on Environmental Health named in full here (RISE) has gained an international recognition thanks to the WFN (15-17). RISE (In French, Rencontres Internationales Santé Environnement) addresses the impact of environmental factors and notably air pollution on the mature and the developing brain and increases the spectrum of neurotoxicology, by including indoor pollution as well as basic principles of neurotoxicology.

This on-going interest in environmental issues is an important endeavour for the WFN. Several initiatives are examined as the WFN and its regional and member organisations seek to strengthen its efforts in this area and to promote brain health, notably with a closer collaboration with the WHO. Developing countries are hardest hit areas in terms of air pollution and its health consequences $(18,19)$, but also in indoor pollution. Awareness research and prevention related to this important topic in developing countries are limited and often also hampered by resources. World brain day activities have introduced this topic to media and encouraged WFN member societies towards awareness and action. But more needs to be done. The World congress of Neurology 2019 (Dubai) is organizing a session on environment and Neurology to promote scientific interest, and update it members on the present state of activities for environment. 


\section{References}

1 Reis J., Öztürk S., Román GC., Spencer PS. History of the WFN Environmental Neurology Research Group. World Neurol. 2016; 31(4):9-10.

2 https://www.wfneurology.org/world-brain-day-2019 Accessed 09.06.2019

3 Wasay M. and Grisold W. World Brain Day 2018 Clean Air for a Healthy Brain.

World Neurol. 2018; 33(2):6.

4 Reis J., Spencer PS., Wasay M., Grisold W., Carroll WM. Clean air for Brain Heath; ongoing agenda of 2018 World Brain Day. J Neurol Sci. 2019; 397:61-62.

5 Meshram C., Singh G. and Thomas S. World Brain Day Celebration in India. World Neurol. 2018; $33(6): 1,3$.

6 Feigin VL., Roth GA., Nathavi M. et al. Global Burden of stroke and risk factors in 188 countries, during 1990-2013: a systematic analysis for the Global Burden of Disease Study 2013. Lancet Neurol 2016; 15: 913-924

7 Hughes SR., Kay P., Brown LE. Global synthesis and critical evaluation of pharmaceutical data sets collected from river systems. Environ Sci Technol. 2013; 47(2) :661-77.

8 Meshram C., and Shakir R. Tropical Neurology: INTROPICON 2018. World Neurol. 2019; 34 (1): 1,3 .

9 Grisold W. Regional WHO Meeting Update. World Neurol. 2017; 32 (5):1,6.

10 Grisold W. Report on the 68th Session of the WHO Regional Committee for Europe. World Neurol. 2018; 33 (6):1,4.

11 Carroll WM. 12-Month Dashboard Report 2019 World Neurol. 2019; 34 (1): 2.

12. https://www.temizhavahakki.com/english/ Accessed 25.04.2019

13 Grisold W., Wasay M., and Reis J. Neurology, Environment and World Brain Day World Neurol. 2018; 33(4): 1-2. 
14 https://www.noroloji.org.tr/menu/11/basinda-biz_Accessed 9 June 2019

15 Anonymous Editorial. Air pollution and brain health: an emerging issue. Lancet 2018; 17:103

16 Spencer PS., Reis J. International Conference Tackles Air Pollution, Emerging Medical Issues. World Neurol. 2017; 31(1): 3.

17 Buguet A., Spencer PS., and Reis J. for the ENRG. Second International Meeting on Environmental Health. World Neurol. 2018; 33(1): 8.

18 Khan M., Wasay M. Environment, pollution and stroke. J Pak Med Assoc, 2018; 68 (7): 984-5. 19 Wasay M. and Khoja A. Environment and Neurological Diseases: Growing Evidence for Direct Relationship. J. Coll. Phys. Surg. Pak. 2018. 28 (5): 337-338. 


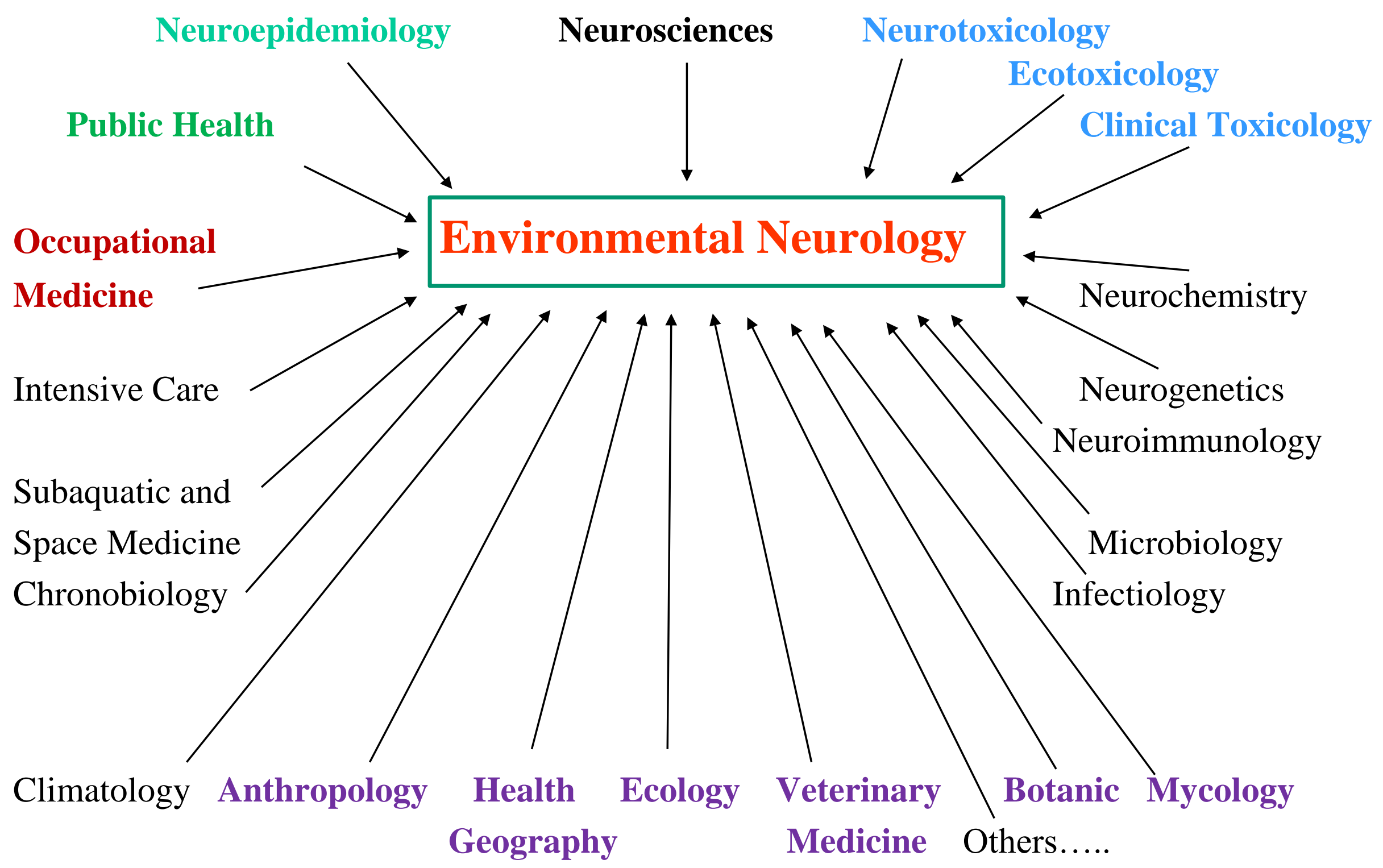

Fig 1 Environmental Neurology provides a translational approach of neurological diseases which is enriched by multiple disciplines 